\title{
Editorial
}

\section{Eventos científicos brasileiros: ampliando a visibilidade da Psicologia Escolar e Educacional}

O II Congresso Brasileiro de Psicologia: ciência e profissão (IICBP) que aconteceu em setembro, em São Paulo, promovido pelo Fórum de Entidades Nacionais da Psicologia Brasileira(FENPB) foi, mais uma vez, o espaço de encontro da Psicologia brasileira. Com a participação de milhares de congressistas provenientes de todo o Brasil e do exterior, permitiu não sómente uma visão mais abrangente e completa da Psicologia mas também que se pudesse conhecer o interesse atual da categoria e dos estudantes e o próprio desenvolvimento da Psicologia. Isso constatou-se pela quantidade e diversidade de atividades que compuseram a programação, pela participação ativa e efetiva de todas as áreas de atuação e investigação psicológica e pela avaliação extremamente positiva feita pelos participantes que preencheram o instrumento de avaliação do congresso.

Cabe destacar a participação da Psicologia Escolar e Educacional no II CBP como área temática que contou com 467 atividades específicas. Vale ressaltar também a efetiva contribuição da Associação Brasileira de Psicologia Escolar e Educacional (ABRAPEE) na secretaria executiva do IICBP e, como membro do FENPB, na organização de atividades que pudessem revelar questões relevantes e em debate na área tanto no tocante à profissão quanto à pesquisa. Tal fato indica a crescente produtividade, visibilidade e expressão da Psicologia Escolar e Educacional no Brasil.

Em se tratando de focalizar eventos científicos, é importante lembrar, para agendar e participar, a realização do VIII Congresso Nacional de Psicologia Escolar e Educacional (CONPE) que acontecerá em abril/2007. Seguindo a tradição da ABRAPEE de realizar seus eventos bianuais em diferentes regiões brasileiras visando congregar profissionais e pesquisadores que se localiam mais distante dos Programas de Pós-graduação em Psicologia Escolar e da própria sede da ABRAPEE, o próximo acontecerá em São Joao Del Rei, Minas Gerais.

A programação está sendo organizada pautada no tema Psicologia Escolar e Educacional: histórias, compromissos e perspectivas. Avançar na história com compromisso de analisar a atual participação da área na ciência e na profissão, enquanto especialidade da Psicologia, visando definir metas de ação, é a proposta de interlocução entre profissionais e estudantes que se espera viabilizar durante o VIII CONPE. Informações podem ser obtidas na página do evento na Internet http://www.viiiconpe.psc.br/, por correio eletrônico (viiconpe@terra.com.br) ou na ABRAPEE (abrapee@terra.com.br). Que possamos publicar nos próximos números da revista artigos resultantes das atividades realizadas no VIIICONPE.

Maria Cristina Rodrigues Azevedo Joly

Editora 